\title{
ANALISIS PENERAPAN MEDIA PEMBELAJARAN DARING DI SEKOLAH DASAR DI MASA PANDEMI COVID-19
}

\author{
Iqnatia Alfiansyah \\ Universitas Muhammadiyah Gresik \\ Corresponding Author E-Mail: iqnatia@umg.ac.id
}

\begin{tabular}{ll}
\hline & \multicolumn{1}{c}{ Abstrak } \\
\hline Kata Kunci: Media & Tujuan penelitian ini adalah untuk menganalisis penerapan media \\
Pembelajaran, Daring & pembelajaran daring di Sekolah Dasar di masa pandemi covid-19. Penelitian \\
& ini menggunakan pendekatan kualitatif dengan jenis penelitian deskriptif. \\
& Penelitian ini memiliki subyek sebanyak 20 pendidik yang tersebar di \\
& berbagai wilayah kabupaten Gresik yang dipilih oleh peneliti dengan \\
& menyesuaikan kebutuhan penelitian. Pembelajaran yang dilaksanakan adalah \\
& pembelajaran secara daring menggunakan gawai (gadget).Analisis masalah \\
& pada penelitian ini didapatkan menggunakan instrument pengisian kuisioner \\
& lewat google forms dan juga wawancara melalui aplikasi Whatsapp. Hasil \\
& dari penelitian ini adalah ditemukan beberapa kendala yang terjadi terkait \\
pelaksanaa pembelajaran secara daring di sekolah dasar. Masalah tersebut & berupa kendala terkait jaringan internet dari pendidik maupun peserta didik, \\
kuota internet yang terbatas, dan waktu pembelajaran yang berubah-ubah.
\end{tabular}

\begin{tabular}{ll}
\hline Keyword: Learning & \multicolumn{1}{c}{ Abstract } \\
Media, Online & $\begin{array}{l}\text { The purpose of this study was to analyze the application of online learning } \\
\text { media in elementary schools during the Covin-19 pandemic. This research } \\
\text { uses a qualitative approach with descriptive research type. This study had as } \\
\text { many as } 20 \text { educators who were scattered in various areas of the Gresik } \\
\text { district who were chosen by the researcher according to the research needs. } \\
\text { The learning that is carried out is online learning using gadgets. Problem } \\
\text { analysis in this study was obtained using a questionnaire filling instrument } \\
\text { via Google Forms and also interviews via the Whatsapp application. The } \\
\text { results of this study were that there were several obstacles that occurred } \\
\text { related to the implementation of online learning in elementary schools. These } \\
\text { problems are in the form of obstacles related to the internet network of } \\
\text { educators and students, limited internet quota, and changing learning times. }\end{array}$ \\
\hline
\end{tabular}

@ Inventa: Jurnal Pendidikan Sekolah Dasar Copy Right

\section{Pendahuluan}

Media masa cetak maupun elektronik sangat gencar memberitakan terkait pandemi covid-19 di berbagai daerah di Indonesia. Jumlah kasus positif, maupun meninggal dunia akibat covid-19 semakin hari semakin bertambah banyak. Hal ini tentu saja membuat pemerintah pusat maupun pemerintah daerah menghimbau warganya untuk menaati protokol Kesehatan dengan sangat ketat. Daerah yang dianggap atau masuk kedalam zona merah covid-19 bahkan sempat menerapkan kebijakan PSBB atau Pembatasan Sosial Berskala Besar. 
Kebijakan ini tentunya berdampak pula pada kebijakan di beberapa sekolah yang terpaksa meliburkan kegiatan tatap muka pembelajaran, dan menggantinya dengan menerapkan pembelajaran dalam jaringan atau pembelajaran daring.

Salah satu kebijakan pemerintah terkait PSBB yang termuat dalam Peraturan Menteri Kesehatan Republik Indonesia Nomor 9 Tahun 2020 adalah diliburkannya sekolah. Maksud diliburkannya sekolah adalah menghentikan proses belajar mengajar secara konvensional kemudian menggantikannya dengan proses belajar di rumah menggunakan teknik atau media tertentu yang efektif. Penentuan media pembelajaran yang paling efektif ini tentunya juga sangat sulit, dikarenakan ada beberapa faktor yang membedakan kondisi di setiap sekolah. Media pembelajaran dikatakan efektif dilihat dari kesesuaian media tersebut dengan kebutuhan dalam suatu pembelajaran bukan dari seberapa canggih atau modernnya sebuah media (Rohani, 2019).

Media pembelajaran yang pada akhirnya dianggap paling efektif diterapkan di masa pandemi ini salah satunya adalah media gawai (gadget). Gawai adalah alat komunikasi yang berukuran kecil sehingga dapat di genggam oleh tangan (Tartila,2020). Laptop dan handphone adalah beberapa contoh dari gawai yang dimaksud yang bisa di gunakan dalam proses pembelajaran secara daring. Penggunaan gawai tersebut tentunya harus diimbangi dengan penggunaan aplikasi tambahan lain untuk membantu kelancaran dari proses pembelajaran secara daring. Aplikasi yang lazimnya digunakan oleh beberapa guru khususnya guru sekolah dasar adalah Whatsapp, Zoom, Edmodo, youtube, dan lainnya. Kombinasi gawai dan aplikasi tersebut juga dibarengi dengan penggunaan sinyal data dan juga kuota internet dari masing-masing pelaku pembelajaran, baik pendidik maupun peserta didik. Hasil dari wawancara dengan beberapa guru sekolah dasar di Gresik memaparkan bahwa, ada sekitar $40 \%$ dari peserta didiknya yang terkendala sulitnya memperoleh sinyal internet dan juga kesulitan menyediakan kuota internet yang dinilai mahal. Hal ini tentu saja akan sangat mempengaruhi kualitas dari proses pembelajaran itu sendiri dan hampir bisa dipastikan akan berpengaruh pada hasil belajar dari peserta didik.

Hasil dari wawancara peneliti dengan beberapa wali peserta didik juga menemukan beberapa keluhan terkait penggunaan gawai yang pada akhirnya disalahgunakan untuk bermain game online sehingga dikhawatirkan akan mengganggu konsentrasi belajar peserta didik. Oleh karenanya kerjasama yang baik dari pendidik, peserta didik dan wali peserta didik sangat dibutuhkan untuk keberhasilan 
pembelajaran menggunakan media gawai yang berbasih daring ini. Seperti pada penelitian yang telah dilakukan oleh (Middleton, 2020) Tidak hanya guru, peneliti pendidikan, dan pembuat kebijakan juga harus bekerja sama dalam meningkatkan kemampuan siswa. Sebab, hasil pengetahuan dari ketiganya juga akan berkontribusi pada hasil pendidikan siswa.

Beberapa penelitian telah dilakukan terkait dengan efektifitas beberapa media pembelajaran online di masa pandemi covid-19 ini. Penelitian mengenai pembelajaran berbasis daring yang pernah dilakukan oleh (Sofyah,2020) misalnya, dengan judul Efektifitas media pembelajaran daring di sekolah dasar. Hasil penelitian tersebut menghasilkan beberapa informasi dari responden yakni media online dikatakan sangat efektif sebesar $35 \%$, efektif $40 \%$ dan menganggap tidak efektif $25 \%$.

Hasil penelitian lain dikemukakan oleh (Herliandry, Nurhasanah, Suban, \& Kuswanto, 2020), pembelajaran online menjadi salah satu alternatif solusi yang efektif untuk mengaktifkan kelas meski sekolah telah ditutup karena adanya pandemi covid-19 ini. Seperti yang telah dibahas sebelumnya, efektif menurut para peneliti sebelumnya tentunya dibarengi dengan metode, strategi, dan model pembelajaran yang cocok. Tidak dapat dilupakan juga peran serta wali peserta didik yang turut membantu mengawasi setiap proses pembelajaran daring ini. Ketersediaan fasilitas dari pemerintah setempat juga diharapkan dapat diandalkan.

Sebagai tambahan, hasil penelitian perbandingan lintas budaya yang dilakukan oleh peneliti dari China, langkah-langkah yang akan direkomendasikan adalah sebagai berikut: mengkaji teori sebelumnya, menyempurnakan metode yang ada secara terus menerus, dan mengembangkan teknik penilaian secara inovatif sesuai dengan skenario aplikasi baru (Su, 2020). Teknik ini tentu saja bisa diterapkan di Indonesia yang notabene memiliki karakteristik yang hampir sama dari segi jumlah kepadatan penduduk dan juga permasalahannya.

\section{Metode}

Penelitian yang dilakukan saat ini menggunakan penelitian dengan pendekatan kualitatif dengan jenis penelitian berupa penelitian deskriptif. Penelitian ini dibantu oleh 20 koresponden yang terdiri dari pendidik sekolah dasar yang ada di berbagai wilayah di kabupaten Gresik. 20 Responden ini dipilih dengan menggunakan Teknik sampling non random sampling dimana peneliti memilih pendidik sesuai dengan kebutuhan dari penelitian yang dilaksanakan. Proses pembelajaran yang dilaksanakan 
menggunakan media gawai laptop dan handphone melalui aplikasi zoom dan youtube. Proses pengambilan data respon dari koresponden didapat melalui pengisian data online atau daring via googleform ditambah dengan wawancara melalui aplikasi perpesanan Whatsapp.

\section{Hasil dan Pembahasan}

Analisis Penerapan Media Pembelajaran Daring di Sekolah Dasar di Masa Pandemi Covid-19 dilakukan dengan memberikan informasi kepada responden yakni pendidik sekolah dasar dibeberapa wilayah gresik untuk pengisian hasil respon melalui google forms. Informasi ini disampaikan melalui grup whatsapp yang telah di buat sebelumnya. Pendidik yang dipilih peserta didik adalah pendidik yang dipilih secara khusus oleh peneliti yang memiliki kondisi sekolah tertentu. Semisal pemilihan pendidik dari daerah Desa Balongpanggang yang mana fasilitas sinyal kadang masih sering terganggu. Kemudian wilayah Gresik Kota dan daerah pesisir pantai di sekitar desa panceng dan Ujungpangkah,

Google Forms yang telah dibuat oleh peneliti berisikan tentang instrument atau media pembelajaran yang digunakan oleh pendidik secara daring, metode, strategi atau model pembelajaran yang digunakan, assessment yang digunakan oleh pendidik saat menggunakan media pembelajaran daring, hasil belajar peserta didik, aktifitas peserta didik saat mengikuti pembelajaran daring, ketersediaan fasilitas gawai bagi pendidik dan peserta didik, dan permasalahan yang sering muncul saat pembelajaran daring.

Selain pengisian googleforms, peneliti juga mengambil data melalui wawancara via aplikasi whatsapp dengan cara mewawancarai secara pribadi bukan melalui grup para pendidik tersebut. Apabila dirasa kurang, peneliti juga akan mewawancarai melalui sambungan telepon agar informasi yang disampaikan dapat tersalurkan dengan baik. Total ada 20 responden pendidik sekolah dasar yang berasal dari berbagai daerah di kabupaten Gresik. Tidak hanya pendidik senior, namun juga pendidik yang masih pemula. Hasil dari wawancara ini dibutuhkan untuk melengkapi hasil respon dari para pendidik yang telah diisi melalui Google Forms.

Berdasarkan hasil penelitian ini, peneliti menganalisis data yang telah diperoleh. Hasilnya adalah beberapa pendidik menghadapi beberapa permasalahan dalam melaksanakan pembelajaran menggunakan media daring ini. Masalah tersebut munsul dikarenakan berbagai sebab. Permasalahan paling umum adalah terkait kekuatan sinyal dan juga besaran paket kuota internet yang digunakan. Hasil ini didapat dari pengisian 
google forms dan juga hasil wawancara. Berikut adalah hasil terperinci dari hasil pengisian googleforms. Berdasarkan hasil pengisian di google forms didapati bahwa $40 \%$ dari para pendidik memilih menggunakan gawainya kolaborasi dengan zoom sebagai media pembelajaran daring. Youtube 50\%, Whatsapp grup $5 \%$, lainnya $5 \%$. Ketika di perlihatkan hasil ini ke pendidik, sebagian besar pendidik memang lebih menyukai pembelajaran via youtube dan zoom. Melalui youtube, pendidik lebih gampang dalam memberikan tutorial sekaligus berceramah meski hanya bisa berjalan 1 arah komunikasi. Selain itu, youtube lebih mudah diakses oleh peserta didik sehingga tidak ada kendala yang muncul. Pilihan kedua adalah aplikasi Zoom. Aplikasi ini bisa diandalkan karena bisa mengakomodasi komunikasi 2 arah antara pendidik dan peserta didik. Pendidik bisa melihat kondisi dan juga bisa menjawab secara lansung pertanyaan dari peserta didik. Kemudian ada Whatsapp grup yang dipilih karena memang beberapa dari pendidik masih ragu atau merasa kurang ahli dalam menggunakan aplikasi yang lain. Sementara aplikasi lainnya seperti Edmodo bisa dimanfaatkan namun memiliki kendala yang lebih banyak.

Hasil berikutnya terkait dengan metode pembelajaran yakni, 60\% lebih memilih membuat video tutorial karena diharapkan video yang telah di rekam dapat disaksikan di waktu yang lain dan diulangi lagi apabila dirasa oleh peserta didik kurang paham. Sementara metode ceramah juga menjadi solusi karena dengan ceramah pendidik bisa memberikan penekanan dan juga rasa kemanusiaan yang tinggi. Metode lain yang di gunakan adalah tanya jawab via Whatssap group yang mana pengguna metode ini sangat kecil sekali prosentasenya dikarenakan memiliki kendala yang besar dalam pelaksanaannya. Berikutnya terkait hasil belajar peserta didik dari pembelajaran via daring dibandingkan dengan pembelajaran luring, menurut $55 \%$ pendidik mengatakan lebih baik hasilnya dibandingkan dengan saat luring. Hal ini tentu saja mengagetkan karena Sebagian besar pendidik mengatakan pembelajaran daring kurang efektif, namun hasil dari penelitian ini didapatkan hasil belajar peserta didik malah lebih baik. Hasil wawancara dengan pendidik mendapat beberapa penjelasan. Hasil yang didapat peserta didik ini bisa jadi dipengaruhi karena kurang maksimalnya materi yang disampaikan oleh pendidik. Hal ini bisa jadi menimbulkan kesan materi yang diajarkan terlalu gampang. Kemudian komentar lain menyebutkan karena hasil belajar ini tidak murni $100 \%$ dari peserta didik, namun ada campur tangan orang tua yang ikut mendampingi dan membantu. Hal ini tentu 
saja menjadi pro kontra terkait permasalah tersebut.

Terkait fasilitas atau tersedianya gawai untuk peserta didik, hasil yang didapat adalah $100 \%$ pendidik memiliki akses untuk menggunakan gawainya sebagai media pembelajaran. Hal ini tentu saja tidak mengherankan mengingat gawai seperti Laptop dan Handphone bisa dikatakan kebutuhan primer untuk saat ini. Hasil yang terakhir terkait masalah yang sering muncul, peneliti membatasi ada 3 masalah utama yang sering muncul. Masalah tersebut adalah sinyal putus/ susah sinyal, kemudian kehabisan kuota internet saat mengikuti pembelajaran, waktu pembelajaran yang kadang tidak sesuai dengan jam yang telah ditentukan karena berbagai kondisi seperti beberapa peserta didik butuh waktu untuk mencari tempat yang memiliki jaringan baik, peserta didik menunggu orang tua atau wali peserta didik untuk bisa menggunakan dawainya dan lain sebagainya. Hasilnya di dapat bahwa $60 \%$ dari pendidik mengatakan bahwa masalah utama yang sering terjadi sinyal putus atau susah sinyal. Pendidik mengutarakan bahwa kadangkala peserta didik mengeluh terpental dari zoom atau suaranya putusputus saat pendidik berceramah.

Sementara itu, Ketika membuka youtube gambar yang disaksikan adalah gambar yang berkualitas $144 \mathrm{p}$ atau maksimal 240p sehingga beberapa detail gambar tidak terlihat. Hasil lainnya didapatkan 20\% mengeluhkan kuota habis. Hal ini dialami selain peserta didik juga dialami oleh pendidik. Beberapa pendidik dan peseerta didik bahkan harus rela ke warung kopi atau balai-balai dikampunya untuk memperoleh akses unternet gratis. Tentunya ini menjadi masalah karena selain pembelajaran terganggu, potensi terjadinya kerumunan yang mengabaikan protokol kesehatan karena ingin mendapat fasilitas internet gratis tersebut. $20 \%$ berikutnya adalah hasil dimana permasalahan waktu pembelajaran daring yang biasanya tidak tepat waktu atau berganti waktu tentunya juga menimbulkan masalah.

Menjadi seorang pendidik, sudah tentu harus siap menghadapi segala permasalahan yang mungkin terjadi selama pembelajaran. Pendidik yang professional adalah pendidik yang mampu menyesuaikan dirinya dan menyelesaikan segala jenis permasalahan dalam pembelajaran. Pendidik dituntuk menjadi kreatif terlebih disaat adanya masa pandemi covid-19. Kreatif dalam memberikan pengajaran dan juga kreatif dalam mengembangkan media pembelajarannya. Pada ranah afektif, guru juga mengalami kesulitan dalam melakukan penilaian. Guru biasanya menilai afektif siswa melalui sikap siswa saat berinteraksi, berdiskusi, berkomunikasi, dan bersosialisasi dengan teman. Tetapi sejak adanya pembelajaran 
daring, guru sangat kesulitan dalam melakukan penilaian afektif (Kuncoro, 2020).

Meskipun pembelajaran saat ini berpusat pada siswa, namun peran dari seorang pendidik tetaplah vital untuk menentukan keberhasilan dari proses pembelajaran. Masa pandemi Covid-19 ini bisa dijadikan alasan agar komunikasi pendidik, peserta didik dan orang tua bisa lebih intensif. Komunikasi yang baik dari ke tiga subyek tersebut akan melahirkan kenyamanan, kualitas, dan hasil belajar yang diinginkan. Masalah yang satu akan terselesaikan namun pastinya akan muncul masalah yang lain.

Permasalahan tersebut tentunya menjadi hal yang wajar dikarenakan system pembelajaran ini baru dilaksanakan pertama kali sejak adanya pandemi covid19. Masalah tetaplah menjadi masalah dan wajib diatasi, bukan lantas menjadi suatu hal yang harus ditakuti atau dihindari. Banyak solusi yang ditawarkan untuk menyelesaikan berbagai permasalahan terkait pembelajaran daring yang dialami dari sisi pendidik. Contohnya seperti mengikuti berbagai seminar yang saat ini sangat masif dilakukan oleh pemerintah maupun pihak lain. Mengikuti workshop dan pelatihan terkait IT juga menjadi salah satu solusi tepat agar para pendidik bisa mulai mengenal dunia gawai dengan baik. Pemikiran dari pendidik yang menganggap gawai adalah salah satu kebutuhan sekunder, harus segera dihilangkan karena mau tidak mau di persaingan global ini, setiap sector dalam berbagai bidang pasti akan memanfaatkan IT. Tidak menutup kemungkinan juga nantinya, pembelajaran setingkat sekolah dasar akan menerapkan Blended Learning yang tentunya mengharapkan sumber daya mumpuni.

Bantuan dari pemerintah tentunya diharapkan senantiasi hadir dalam membantu setiap permasalahan yang muncul. Bantuan kuota data internet yang dibeberikan oleh pemerintah memberikan angin segar bagi pendidik maupun peserta didik, meskipun belum terdistribusi secara merata. Pemberian atau pembangunan fasilitas belajar seperti perbaikan kualitas sinyal dibeberapa wilayah tentunya diharapkan agar masalah koneksi internet juga bisa terhindarkan.

\section{Kesimpulan}

Media pembelajaran yang digunakan secara daring adalah menggunakan gawai yang dikolaborasikan dengan aplikasi dari pihak ke tiga seperti zoom, youtube, dan lainnya. Pemilihan media tersebut dilakukan dengan berbagai pertimbangan melihat dari kemudahan dan kelebihannya meskipun menyisakan kekurangan dan masalah yang dirasa sangat berat oleh sebagian pendidik. Masalah tersebut 
diantaranya adalah kesulitan dari guru untuk mengoperasikan gawainya sehingga harus memerlukan bantuan orang lain yang dianggap ahli. Masalah lainnya adalah berdasarkan analisis dari beberapa pendidik, pembelajaran via daring ini dianggap kurang berkualitas.

Berangkat dari masalah tersebut, pendidik berinisiatif membuat program belajar secara daring menggunakan dawai dikolaborasikan dengan aplikasi popular seperti youtube dan zoom. Melalui cara tersebut pendidik merasa kesulitan mengajar di masa pandemi covid-19 ini menjadi lebih mudah. Metode belajar menggunakan pemberian video tutorial dianggap lebih efektif karena bisa ditampilkan disetiap waktu/sehingga pembelajaran bagi peserta didik tidak terbatas. Penggunaan Zoom juga bisa mengakomodasi komunikasi secara 2 arah agar tanya jawab pendidik dan peserta didik tetap berjalan dengan baik. Kendala sinyal atau jaringan yang kurang kuat dan juga kuota internet menjadi permasalahan yang sulit diselesaikan tanpa campur tangan dari pemerintah.

\section{Daftar Pustaka}

Anugrahana, A. (2020). Hambatan, Solusi dan Harapan: Pembelajaran Daring Selama Masa Pandemi Covid-19 Oleh Guru Sekolah Dasar. Scholaria: Jurnal
Pendidikan

dan

Kebudayaan, 10(3), 282-289.

Ameli, A., Hasanah, U., Rahman, H., \& Putra, A. M. (2020). Analisis Keefektifan Pembelajaran Online di Masa Pandemi Covid19. Mahaguru: Jurnal Pendidikan Guru Sekolah Dasar, 2(1), 28-37.

Angrist, N., Bergman, P., Evans, D. K., Hares, S., Jukes, M. C., \& Letsomo, T. (2020). Practical Lessons for Phone Based Assessments of Learning. BMJ Global Health, 1-6. Arikunto, S. (2010). Prosedur Penelitian . Jakarta: Rineka cipta.

Herliandry, L. D., Nurhasanah, Suban, M. E., \& Kuswanto, H. (2020). Pembelajaran pada Masa Pandemi Covid-19. Jurnal Teknologi Pendidikan, 65-70.

Lestari, S. w. (2020). Kendala Pelaksanaan Pembelajaran Jarak Jauh (PJJ) dalam Masa Pandemi Ditinjau dari Media Pembelajaran. Academia, 16.

Middleton, K. V. (2020). The Longer-Term Impact of COVID-19 on K-12 Student Learning and Assessment. Educational Measurement Issues and Practice, 1-4.

Mustakim. (2020).

Efektivitas

Pembelajaran Daring Menggunakan Media Online Selama Pandemi Covid-19 pada Mata Pelajaran 
Matematika. Journal of Islamic

Education, 1-10.

Purwanto, A., Pramono, R., Asbari, M., Hyun, C. C., Wijayanti, L. M., \& Putri, R. S. (2020). Studi Eksploratif

Dampak Pandemi COVID-19

Terhadap Proses Pembelajaran

Online di Sekolah

Dasar. EduPsyCouns: Journal of

Education, Psychology and

Counseling, 2(1), 1-12.

Su, H. (2020). Educational Assessment of the Post-Pandemic Age: Chinese Experiences and Trends Based on Large-Scale Online Learning. Educational Measurement Issues and Practice, 1-4.

Sugiyono. (2008). Metode Penelitian

Kuantitatif dan Kualitatif. Bandung:

Alfabeta. 